\title{
MANUFACTURING LOCATION: THE IMPACT OF HUMAN CAPITAL STOCKS AND FLOWS
}

\author{
Kevin T. McNamara, Warren P. Kriesel, and Brady J. Deaton*
}

National attention has been focused on the importance of education to rural economic development by several recent studies (Ford Foundation, 1986; Rosenfeld, Bergman, and Rubin, 1985; Southern Growth Policies Board, 1985). Manufacturing location and employment growth studies, however, have presented conflicting evidence about the relationship between human capital and local economic development (McNamara, Kriesel, and Deaton, 1988). While insight into this relationship holds important education policy implications for all levels of government, it is particularly critical for rural governments as rural communities attempt to stabilize and strengthen their economic bases. This paper reports the results of a manufacturing firm location study that incorporated measures for both human capital stocks and flows into a statistical model of community attributes that were hypothesized to influence firm location decisions. The results indicate the complexity of evaluating the impact of human capital investment on local or regional economic growth. Given the significance of the human factors to the location decisions of firms, it is surprising that so little attention has been given to these issues.

\section{Firm Location Decisions}

The reaction of firms to communities at various educational levels, ceteris paribus, is predicted by standard neoclassical theory; that is, firms will estimate the MVP of local labor to the firm and locate where their profits are greatest. Recognizing that there is foregone production due to training, profit maximizing firms may seek to reduce labor costs by selecting communities with a higher educational investment, or those that offer a different mix of training services, vocational schools, and community colleges. A firm which locates in a community that has allocated greater investments to education is expected to obtain higher productivity, and the community is rewarded with increased economic opportunity. Clearly,

\footnotetext{
*The authors are, respectively, assistant professor and rural development economist, Institute of Community and Area Development and Department of Agricultural Economics, University of Georgia, Athens, Ga; research assistant, Department of Agricultural Economics, Ohio State University, Columbus, Ohio; and, professor and associate director of international development, Virginia Polytechnic Institute, Blacksburg, Va.
}

firms will seek to match their labor needs to the community in which appropriate labor can be obtained or developed at the lowest cost.

Little research has been undertaken that relates local human capital investments through public education to changes in the local economy, changes in local demand for labor, or changes in the local demand for other public goods and services. The link between education as a form of human capital investment and industrial growth rests on the theory that human capital investment improves the quality of the labor force and, thereby, the value of the labor input to the production processes of the local economy (Welch, 1975). Selecting variables to measure the effects of local human capital investment through public education, therefore, warrants serious research attention.

Human capital resources can be divided into stock and flow resources with each type having a potentially different impact on economic growth (McNamara, Kriesel, and Deaton, 1988). Human capital stocks are the current levels of education and skills in the work force after migration and other adjustments have occurred. Included here would be investments in maintenance that simply preserves or holds constant an existing level of human capital stock. Certain investments in health care and onthe-job training would likely fall in this category. They do not add new skills to the individual, but simply maintain an existing level of skills. To the extent that new skill training is embodied in the training program, such investments would alter the flow of human capital. Human capital flows, on the other hand, are the current levels of human capital being produced or added to local human capital stocks through such activities as public and private education systems, health care services, and changes in commuting or migration patterns.

Past research on local economic development has used manufacturing locations and employment changes as growth measures (Debertin, Pagoulatos, and Smith, 1980; Smith, Deaton, and Kelch, 1978; Kamer, 1979) in econometric models to examine community factors influencing economic growth. The hypothesis that human capital stocks and flows influence industrial location decisions is derived from the theory of spatial profit maximization in firm locations, even though stocks and flows are not distinctly specified, or even recognized, in most studies (Smith, 1981). 
Local human capital stocks and flows are hypothesized to affect the cost structure of firms within this secondary site search level (Smith, Deaton, and Kelch, 1978). Lower labor tumover, a more trainable work force, and greater labor productivity are benefits that accrue to firms that hire employees with higher levels of education or a greater stock of human capital. Because they reflect the community's quality of life, local educational attributes also are hypothesized to influence firm managers' non-economic judgments in the location decision process. Relocated managers and workers demand a certain level of educational and other public services for their families.

Undoubtedly, some cheap labor markets represent a paradox for firm management. The cheap labormay attract firms which require minimum skills. On the other hand, these areas may not provide the amenities that will attract plant managers and skilled labor. Increasingly, lowskilled plants have moved abroad and it is likely that most manufacturing plants are looking for communities with the potential of providing quality recreational, educational, and other aesthetic features. Such communities are also attractive for long-term growth of the firm and potential upgrading of skill requirements.

A number of location and manufacturing growth studies have attempted to identify factors that influence local economic growth. While the theoretical basis for factor influence has not always been clear, the studies are based implicitly on the theory of spatial profit maximization (i.e., least-cost production). Table 1 summarizes the results for 10 such manufacturing location studies which employed 12 variables describing the quality of the local work force. The estimated coefficients measuring the relationship of these variables to manufacturing growth are widely divergent. The signs of the estimated regression coefficients were as hypothesized and were significant in three studies (Kuehn, Braschler, and Shonkwiler, 1979; Smith, Deaton, and Kelch, 1978; Debertin, Pagoulatos, and Smith, 1980) and significant with the wrong sign in two studies (Sulaiman and Hushak, 1980; Leuck, 1979). Seven variables in six studies were insignificant. A number of alternative reasons are usually offered as to why the signs are contrary to the hypotheses.

An educational expenditure measure was used in three plant location studies which analyzed identical data sets (based on primary data from Kentucky and Tennessee) and varied only by model specification. Studies by Debertin, Pagoulatos, and Smith and by Smith, Deaton, and Kelch obtained positive significant results, while another by Smith and Klindt used dummy variables to describe regional differences and found the variable to be insignificant. In a study of employment changes, Leuck obtained negative significant results with this measure. Four studies used a proxy variable related to the level of local educational attainment (Kamer, 1979; Wheat, 1976; Sulaiman and Hushak, 1980; Agthe and Billings, 1977). The variable was significant and negative in one study and nonsignificant in the other studies. Other measures related to labor quality included a health expenditure variable used in two studies (Dorf and Emerson, 1978; Leuck, 1979) and a welfare expenditure variable in one (Leuck, 1979). None of these variables was statistically significant.

Given the wide variety of proxy variables used without precise theoretical underpinnings, conflicting results in these studies are difficult to interpret and do not provide insight into the development of appropriate human capital measures. This literature does, however, reflect that researchers expect a positive functional relationship to be revealed between education as an investment in human capital and economic development, even though this relationship is not explicitly treated in any of the studies.

Differentiating between the stock and flow dimensions of human capital provides a basis for reconsidering the labor quality variables from Table 1 . Of the two studies showing unexpected signs on the human capital proxy variables, one used a stock measure (Sulaiman and Hushak, 1980), while the other had a flow measure (Leuck, 1979). In the three studies which had the expected sign for the human capital measures, flow measures were used (Kuehn, Braschler, and Shonkwiler, 1979; Debertin, Pagoulatos, and Smith, 1980; Smith, Deaton and Kelch, 1978). Distance to a technical school measures access to staff training. School expenditures are a proxy for local human capital investment through public education. The five remaining studies found insignificant relationships. Flow measures were used in the studies by Smith and Klindt, Dorf and Emerson, and Leuck. Stock measures were used by Kamer and by Agthe and Billings. On balance, the flow measures seemed to yield results more consistent with theoretical expectations.

\section{An Industrial Location Model for Virginia}

In an attempt to clarify the linkages between human capital investment and growth in manufacturing, a logit model (similar to that of Debertin, Pagoulatos, and Smith, 1980) was specified for Virginia localities. Stock and flow measures of human capital were employed, with the hypothesis that both would have a positive association with industrial location patterns.

Location theory, a neoclassical model that bases firm location decisions on a least cost or profit maximization criterion (Smith, 1981), provides the theoretical basis for this analysis. This theory views location decision as a twostage process. First, footloose firms identify a geographi- 
Table 1

Measures of Human Capital Investment and Their Roles in Various Industrial Location Models

\begin{tabular}{|c|c|c|c|c|c|}
\hline $\begin{array}{l}\text { Study } \\
\text { Region }\end{array}$ & $\begin{array}{l}\text { Unit of } \\
\text { Model }\end{array}$ & $\begin{array}{l}\text { Dependent } \\
\text { Observation }\end{array}$ & $\begin{array}{l}\text { Human } \\
\text { Variable }\end{array}$ & Capital Proxy & Result \\
\hline $\begin{array}{l}\text { Missouri } \\
(1)^{*}\end{array}$ & $\begin{array}{l}\text { Linear } \\
\text { Probability }\end{array}$ & $\begin{array}{l}\text { Small } \\
\text { Rural }\end{array}$ & $\begin{array}{l}\text { Plant } \\
\text { Location }\end{array}$ & $\begin{array}{l}\text { Distance to } \\
\text { Technical School }\end{array}$ & $\begin{array}{l}\text { Negative } \\
\text { (Significant) }\end{array}$ \\
\hline $\begin{array}{l}\text { Kentucky- } \\
\text { Tennessee (2) }\end{array}$ & Logit & $\begin{array}{l}\text { Non-SMSA } \\
\text { Towns }\end{array}$ & $\begin{array}{l}\text { Plant } \\
\text { Location }\end{array}$ & $\begin{array}{l}\text { Educational } \\
\text { Expenditures }\end{array}$ & $\begin{array}{l}\text { Positive } \\
\text { (Significant) }\end{array}$ \\
\hline $\begin{array}{l}\text { Kentucky- } \\
\text { Tennessee (3) }\end{array}$ & $\begin{array}{l}\text { Linear } \\
\text { Probability }\end{array}$ & $\begin{array}{l}\text { Non-SMSA } \\
\text { Towns }\end{array}$ & $\begin{array}{l}\text { Plant } \\
\text { Location }\end{array}$ & $\begin{array}{l}\text { Educational } \\
\text { Expenditures }\end{array}$ & $\begin{array}{l}\text { Positive } \\
\text { (Significant) }\end{array}$ \\
\hline $\begin{array}{l}\text { Kentucky- } \\
\text { Tennessee (4) }\end{array}$ & $\begin{array}{l}\text { Linear } \\
\text { Probability }\end{array}$ & $\begin{array}{l}\text { Non-SMSA } \\
\text { Towns }\end{array}$ & $\begin{array}{l}\text { Plant } \\
\text { Location }\end{array}$ & $\begin{array}{l}\text { Educational } \\
\text { Expenditures }\end{array}$ & $\begin{array}{l}\text { Not } \\
\text { Significant }\end{array}$ \\
\hline $\begin{array}{l}\text { United } \\
\text { States (5) }\end{array}$ & $\begin{array}{l}\text { Ordinary } \\
\text { Least Squares }\end{array}$ & SMSAs & $\begin{array}{l}\text { Manufacturing } \\
\text { Employment Growth }\end{array}$ & $\begin{array}{l}\text { Number of Persons Age } \\
25 \text { with College Degree }\end{array}$ & $\begin{array}{l}\text { Positive or Negative, } \\
\text { by Industry }\end{array}$ \\
\hline $\begin{array}{l}\text { Southern } \\
\text { United States (6) }\end{array}$ & $\begin{array}{l}\text { Ordinary } \\
\text { Least Squares }\end{array}$ & $\begin{array}{l}\text { Non-SMSA } \\
\text { Cities }\end{array}$ & $\begin{array}{l}\text { Population } \\
\text { Growth }\end{array}$ & $\begin{array}{l}\text { Percentage of } \\
\text { Teenagers in School }\end{array}$ & $\begin{array}{l}\text { Not } \\
\text { Significant }\end{array}$ \\
\hline $\begin{array}{l}\text { Ohio } \\
\text { (7) }\end{array}$ & $\begin{array}{l}\text { Ordinary } \\
\text { Least Squares }\end{array}$ & $\begin{array}{l}\text { Appalachian } \\
\text { Counties }\end{array}$ & $\begin{array}{l}\text { Manufacturing } \\
\text { Employment Growth }\end{array}$ & $\begin{array}{l}\text { Median } \\
\text { School Years }\end{array}$ & $\begin{array}{l}\text { Negative } \\
\text { (Significant) }\end{array}$ \\
\hline $\begin{array}{l}\text { Southeastern } \\
\text { United States (8) }\end{array}$ & $\begin{array}{l}\text { Ordinary } \\
\text { Least Squares }\end{array}$ & $\begin{array}{l}\text { Industrial } \\
\text { Parks }\end{array}$ & $\begin{array}{l}\text { Plant } \\
\text { Location }\end{array}$ & $\begin{array}{l}\text { Average Male } \\
\text { Education }\end{array}$ & $\begin{array}{l}\text { Not } \\
\text { Significant }\end{array}$ \\
\hline $\begin{array}{l}\text { Northern Central } \\
\text { United States (9) }\end{array}$ & $\begin{array}{l}\text { Factor } \\
\text { Analysis }\end{array}$ & $\begin{array}{l}\text { Non-SMSA } \\
\text { Cities }\end{array}$ & $\begin{array}{l}\text { Change in } \\
\text { Number of Plants }\end{array}$ & $\begin{array}{l}\text { Health } \\
\text { Expenditures }\end{array}$ & $\begin{array}{l}\text { Not } \\
\text { Significant }\end{array}$ \\
\hline $\begin{array}{l}\text { Tennessee } \\
(10)\end{array}$ & $\begin{array}{l}\text { Factor } \\
\text { Analysis }\end{array}$ & $\begin{array}{l}\text { Non-SMSA } \\
\text { Counties }\end{array}$ & $\begin{array}{l}\text { Manufacturing } \\
\text { Employment Growth }\end{array}$ & $\begin{array}{l}\text { Education } \\
\text { Expenditures } \\
\text { Health } \\
\text { Expenditures } \\
\text { Welfare } \\
\text { Expenditures }\end{array}$ & $\begin{array}{l}\text { Negative } \\
\text { (Significant) } \\
\text { Not } \\
\text { Significant } \\
\text { Not } \\
\text { Significant }\end{array}$ \\
\hline
\end{tabular}

*Numbers in parentheses refer to authors as follows:
(1) Kuehn, Braschler, and Shonkwiler
(6) Wheat
(2) Debertin, Pagoulatos, and Smith
(7) Sulaiman and Hushak
(3) Smith, Deaton, and Kelch
(8) Agthe and Billings
(4) Smith and Klindt
(5) Kamer
(9) Dorf and Emerson
(10) Leuck

cal region to optimize factor supply and product market access. Second, firms select a site within the region on a minimum cost of production criteria. Cost factors include agglomeration economies, labor availability, labor costs, access to input factors and product markets, the community's eagerness for industrial development, indus- trial site quality, human capital, an area's quality of life, and miscellaneous firm cost factors (Kriesel, 1983).

The independent variables included in this study are those location factors that were found to be significant variables in the research cited in Table 1. The firm cost factor that each independent variable represents is listed 
under the proxy column.

The model uses a dichotomous dependent variable ( 1 = one or more new manufacturing plants, $0=$ no new plants) to account for the "success" of a community in attracting a plant with at least 15 employees during the three-year period 1979-81. The county/city is the unit of observation and, cross-sectional data for Virginia's 136 counties and cities are used in the study. A Pearson correlation test indicated no serious pairwise correlation. The stock and flow measure had a correlation coefficient of 0.56 .

All data are from secondary sources, except for the dependent variable and the development group variable, which were obtained from a mail survey. Two human capital flow measures are used, one being the fourth grade math score, ${ }^{1}$ and the other, the distance to the nearest fouryear college. Both of these variables are proxies for human capital flows because they represent current investment in education. The achievement score represents the quality of current public school students who will enter the work force. The college measure reflects adult access to education, which adds to the human capital base of the work force. The stock measure was the percentage of persons older than 25 with a high school diploma.

The empirical model was the following:

$$
\begin{aligned}
\mathrm{L}= & \text { M4, GRADS, COL, POP, EMPHRS, } \\
& \text { SMSAMI, PCRACE, DEVG, EFFREAL, } \\
& \text { WAGE, FPR, }
\end{aligned}
$$

where

$\begin{array}{ll}\mathrm{L}= & \text { dichotomous variables for plant loca- } \\ & \text { tion, } \\ \mathrm{M} 4 & \text { fourth-grade math achievement test } \\ & \text { score, }\end{array}$

A summary of the model is presented in Table 2. The correct prediction rate (a substitute for $R^{2}$ when $1-0$ dependent variables are employed) is 80 percent. The full model's Chi-square statistic is significant at the 0.0001 level. Two variables, $P O P$ and $D E V G$, are significant at the 0.025 level, and each has the hypothesized sign. The two human capital variables are significant at the 0.05 level. Math scores, the flow measure, had the hypothesized positive influence. The effect of GRADS, the stock measure, had a negative sign, contrary to what was hypothesized.

The significance of the population variable, $P O P$, supports the hypothesis that agglomeration economies reduce firms' costs and provide a cost-reducing incentive to footloose firms. This result is consistent with earlier studies. The other agglomeration variable, EMPHRS, is not statistically significant. The development group variable, DEVG, supports the hypothesis that local site marketing increases local development potential (Kriesel, 1983).

The results of the human capital stock and flow measures, however, present new insight into the complex relationship between human capital investment and local economic growth. The human capital flow measure, $M 4$, is significant and positive. This measure, the mean fourth grade standardized math achievement test score, was chosen as a proxy for the amount of human capital being produced in the local school system. The variable's significance supports the hypothesis that footloose firms are interested in educational quality when making location decisions. High quality education increases the productivity of the work force and provides a quality of life inducement for managers whom the firm will relocate to the new plant site (Hekman, 1982).

The human capital stock measure, GRADS, has a negative association with location. Schultz (1961) argues that human capital investment must always increase the productivity of labor and that the rate of return on these investments will always be positive. He recognized, however, that observed rates of return may be positive, zero, or negative in the real world because of imperfect knowledge and uncertainty which results in estimations contrary to expectations.

Costs of information to the firm may also provide an explanation of the conflicting impacts of human capital stock and flows. That is, firms are limited in the resources they can devote to the site location process, as implied by Stigler's theory of search (Oster, 1979). As this theory is applied to firm location, the gains from search are found to increase with input levels, variance of input costs, and the covariance of cost distributions. Here, with education levels (as an input) being only one consideration among a myriad of location factors which have more predictable 
Table 2

Independent Variables Used in Industrial Location Model: Virginia, 1979-1983

\begin{tabular}{|c|c|c|c|c|c|}
\hline & & Variable & Proxy & Specification & Logit Estimates \\
\hline & 1. & M4 & $\begin{array}{l}\text { Human } \\
\text { Capital }\end{array}$ & $\begin{array}{l}\text { Math Test Results } \\
\text { for Fourth Grade, } 1980\end{array}$ & $\begin{array}{l}0.05902 * \\
(0.03276)\end{array}$ \\
\hline & 2. & GRADS & $\begin{array}{l}\text { Human } \\
\text { Capital }\end{array}$ & $\begin{array}{l}\text { Percentage of Persons Age } 25 \\
\text { with High School Diploma }\end{array}$ & $\begin{array}{l}-0.05866^{*} \\
(0.03405)\end{array}$ \\
\hline & 3. & $\mathrm{COL}$ & $\begin{array}{l}\text { Human } \\
\text { Capital }\end{array}$ & $\begin{array}{l}\text { Distance to } \\
\text { Nearest College }\end{array}$ & $\begin{array}{l}-0.00393 \\
(0.00884)\end{array}$ \\
\hline & 4. & POP & Agglomeration & Population, 1980 & $\begin{array}{l}0.00002 * * \\
(0.00001)\end{array}$ \\
\hline & 5. & EMPHRS & Agglomeration & $\begin{array}{l}\text { Manufacturing } \\
\text { Employment Hours }\end{array}$ & $\begin{array}{l}0.00003 \\
(0.00009)\end{array}$ \\
\hline & 6. & SMSAMI & Market Access & $\begin{array}{l}\text { Miles to Center } \\
\text { of SMSA }\end{array}$ & $\begin{array}{l}0.01112 \\
(0.01272)\end{array}$ \\
\hline & 7. & PCRACE & $\begin{array}{l}\text { Discrimination } \\
\text { of Blacks }\end{array}$ & Percentage & $\begin{array}{l}-0.00948 \\
(0.01572)\end{array}$ \\
\hline & 8. & DEVG & $\begin{array}{l}\text { Site Marketing } \\
\text { (Eagerness) }\end{array}$ & $\begin{array}{l}\text { Existance of Funded } \\
\text { Development Group }\end{array}$ & $\begin{array}{l}0.91483^{* *} \\
(0.42601)\end{array}$ \\
\hline & 9. & EFFREAL & $\begin{array}{l}\text { Firms' } \\
\text { Costs }\end{array}$ & $\begin{array}{l}\text { Effective Real } \\
\text { Estate Tax, } 1978\end{array}$ & $\begin{array}{l}0.54260 \\
(0.77830)\end{array}$ \\
\hline & 10. & WAGE & $\begin{array}{l}\text { Labor } \\
\text { Costs }\end{array}$ & $\begin{array}{l}\text { Average Manufacturing } \\
\text { Wages, } 1978\end{array}$ & $\begin{array}{l}0.00020 \\
(0.00368)\end{array}$ \\
\hline & 11. & FPR & $\begin{array}{l}\text { Firms' } \\
\text { Costs }\end{array}$ & $\begin{array}{l}\text { Fire Protection } \\
\text { Rating, } 1978\end{array}$ & $\begin{array}{l}0.17179 \\
(0.17025)\end{array}$ \\
\hline & 12. & INTERCEPT & & & $\begin{array}{l}-2.64032 \\
(2.09033)\end{array}$ \\
\hline
\end{tabular}

* Significant at 0.05

**Significant at 0.025

Standard errors are in parentheses.

$\mathbf{N}=136$

Model's Chi-square was significant at $p=0.0001$ level, with correct prediction rate $=0.80$.

impacts on profits, it can be expected that firms will devote less attention to identifying pools of skilled labor, particularly if the cost of employing skilled labor has a small variance. This observation suggests that firms base their location decision more on labor costs or factors associated with the size economies, reflected in the agglomeration measures, than on education levels, and that these firms may have relatively poor information regarding skill levels.

Another factor that might help explain the negative association of the human capital stock measure and location is aggregation of data. Manufacturing employment or firm location data are not disaggregated by Standard Industrial Classification code in the estimated models. This 
aggregation may have grouped firms together that are actually seeking different labor skills and which react differently to the local stock and flow of human capital. The small number of locations per industry in Virginia make disaggregation to test this hypothesis impossible when using this type of analysis.

Hekman's study supports this aggregation argument. He finds that similar types of manufacturing firms exhibit varying demands for skilled labor inputs. In his study, 194 newly-located firms in the Southeastern United States were asked to rate 19 location factors in order of importance. The firms represented nineteen of the 20 two-digit SIC codes for manufacturing. Within those groups there were only three instances where strong importance was given to a skilled labor supply. Within all of the other groups, skilled and unskilled labor supply showed about the same importance. For example, chemical firms rated unskilled labor supply as 15 th in importance and simultaneously rated skilled labor supply as 14 th. In other words, these firms need to draw on both skilled and unskilled labor from the local labor market.

Clearly, a single measure of available human capital for a given locality is inadequate for capturing the diverse range of skills that firms seek, rendering such aggregate analysis very imprecise. More than one measure will probably have to be used to capture the influence of the diversity of labor that firms seek or else labor demand will have to be analyzed by firm type. Alternative types of analyses should be employed in order to gain greater insight into this issue.

\section{Conclusions}

The results presented in this paper support the hypothesis that human capital stocks and flows have unique impacts on local economic development. The flow variable, a measure of local school quality, is positively associated with location decisions of manufacturing plants. The stock measure, on the other hand, has a negative association.

The implications of the above analysis for local government public policy are significant. First, policymakers must consider the potential impact that changes in school expenditures will have on educational achievement. Changes that reduce school performance could reduce local development potential. Plant location decisions seem to be more dependent on educational flow measures than on the accumulated stock measures. Firms most likely consider simultaneously the importance of education to those families who may be transferred to a locality to establish the new facility and/or the potential of the educational resources of the community for providing specialized skill training for the future work force. Second, human capital stocks, as measured by the percentage of the population with high school diplomas, may be of less importance in manufacturing location decisions than human capital flows due to the firm's ability to attract laborers with certain basic skills from a broader labor market area.

In future research, more attention should be given to establishing the proper conceptual framework for linking local investments in schooling and other forms of increasing labor quality with different patterns of economic development. Secondary data may be too aggregated and SIC codes may not be refined enough to differentiate labor skill needs. Most likely, a more refined delineation of industry by its specialized demand for human capital will be required in order to obtain parameter estimates that will serve to guide public policy, local decision making, and future research.

\section{Notes}

${ }^{1}$ Models were also estimated with eighth- and 11 th-grade scores (the only other grades for which data are available) with similar results.

\section{References}

Agthe, Donald E., and R. Billings Bruce. "The Importance of Community Economic Factors in the Success of Public Industrial Parks: A Case Study of the Southeast." Business and Economic Review. 24 (1977). 3-6.

Debertin, David L., Angelos Pagoulatos, and Eldon D. Smith. "Estimating Linear Production Functions: A Comparison of Approaches." Southern Journal Of Agricultural Economics. 12 (1980). 65-69.

Dorf, R. J., and M. Emerson. "Determinants of Manufacturing Plant Location for Nonmetropolitan Communities in the West North Central Region of the U.S." Journal of Regional Science. 18 (1978). 109-120.

Ford Foundation. "Shadows in the Sunbelt: Developing the Rural South in an Era of Economic Change." A Report of the MDC Panel on Rural Economic Development, May 1986.

Heloman, John S. "Survey of Location Decisions in the South." Federal Bank of Atlanta Economic Review. 6 (1982). 6-19.

Kamer, Pearl M. "An Econometric Model to Evaluate the Competitive Position of U.S. Metropolitan Areas for Manufacturing Activity." Socio-Economic Planning Sciences. 13 (1979). 227-234.

Kuehn, John A., Curtis Braschler, and J. Scott Shonkwiler. "Rural Industrialization and Community Action: New Plant Locations Among Missouri's Small Towns." Journal of The Community Development Society. 10 (1979). 95-107. 
Kriesel, Warren. "The Estimation of Benefits, Costs and Probabilities of Manufacturing Plant Location in Rural Virginia." Unpublished Master's Thesis. Blacksburg, Va.: Virginia Polytechnic Institute, 1983.

Leuck, D. J. "An Econometric Model of Manufacturing Growth in Rural Employment in Rural Tennessee Counties From 1962 to 1976." Southern Journal of Agricultural Economics. 11 (1979). 63-67.

McNamara, Kevin T., Warren P. Kriesel, and Brady J. Deaton. "Human Capital Stock and Flow and Economic Growth Analysis." Growth and Change. 19:1 (Winter 1988). 6166.

Oster, S. "Industrial Search for New Locations: An Empirical Analysis." The Review of Economics and Statistics. 61 (1979). 288-292.

Rosenfeld, Stuart A., Edward M. Bergmar, and Sara Rubin. After the Factories: Changing Employment Patterns in the Rural South. Research Triangle Park, N.C.: Southern Growth Policies Board, 1985.

Schultz, T.W. "Investment in Human Capital" American Economic Review. 51 (1961). 1-17.
Smith, David M. Industrial Location. New York: John Wiley \& Sons, 1981.

Smith, Eldon D., Brady J. Deaton, and David R. Kelch. "Location Determinants of Manufacturing Industry in Rural Areas." Southern Journal of Agricultural Economics. 10 (1978). 23-32.

Smith, Eldon and Thomas H. Klindt. Industrial Location and Growth in Submetro Tennessee and Kentucky Communities. Southem Cooperative Series Bulletin 258, June 1981.

Southern Growth Polices Board. Halfway Home and A Long Way to Go: The Report of the 1986 Commission on the Future of the South. Research Triangle Park, N.C.: Southern Growth Policies Board, 1985.

Sulaiman, Jamalludin, and Leroy J. Hushak. "The Impact of Industrial Sites on Industrial Employment Growth: A Case Study of Appalachian Ohio." The American Industrial Development Council Journal. 15 (1980). 7-22.

Welch, Finis. "Human Capital Theory: Education, Discrimination, and Life Cycles." American Economic Review. 65 (1975). 53-73.

Wheat, Leonard. Urban Growth in the Nonmetropolitan South. Lexington, Mass.: Lexington Books, 1976. 